\title{
Erratum to: Expressed Emotion, Parental Stress, and Family Dysfunction Among Parents of Nonclinical Italian Children
}

Elisa Delvecchio - Daniela Di Riso •

Daphne Chessa • Silvia Salcuni •

Claudia Mazzeschi • Loredana Laghezza

Published online: 28 January 2014

(C) Springer Science+Business Media New York 2014

Erratum to: J Child Fam Stud

DOI 10.1007/s10826-013-9754-x

The authors state that the translation and use of the Italian PAM in the original paper was not authorized by PAR. PAR did not give them the authorization. They regret the inconvenience caused in this regard.

The online version of the original article can be found under doi:10.1007/s10826-013-9754-x.

E. Delvecchio $(\bowtie) \cdot$ D. Di Riso · D. Chessa · S. Salcuni Department of Developmental Psychology and Socialization, University of Padova, c/o LIRIPAC, Via Belzoni, 80,

35100 Padua, Italy

e-mail: elisa_delvecchio@libero.it

C. Mazzeschi · L. Laghezza

Department of Human Science and Education, University of Perugia, Perugia, Italy 